\title{
Pemilihan Antibiotika pada Anjing Diare yang Terinfeksi Escherichia coli
}

\author{
Antibiotic of Choice for Diarrhea on Dogs Caused by Escherichia coli
Soedarmanto Indarjulianto ${ }^{1 *}$, Sitarina Widyarini ${ }^{2}$, Gede Bayu Suparta ${ }^{3}$, Alfarisa Nururrozi ${ }^{1}$, Yanuartono ${ }^{1}$, Slamet Raharjo ${ }^{1}$, Yeremia Yobelanno Sitompul ${ }^{4}$, Ika Tidariani ${ }^{5}$, Anna Ekawati ${ }^{6}$, Mega Cahya Nalasukma ${ }^{7}$

\author{
${ }^{1}$ Departemen Ilmu Penyakit Dalam, Fakultas Kedokteran Hewan, Universitas Gadjah Mada, Yogyakarta \\ ${ }^{2}$ Departemen Patologi, Fakultas Kedokteran Hewan, Universitas Gadjah Mada, Yogyakarta, 55281. \\ ${ }^{3}$ Departemen Fisika, Fakultas Matematika dan Ilmu Pengetahuan Alam, Universitas Gadjah Mada. \\ Sekip Utara, Bulaksumur, Yogyakarta, 55281. \\ ${ }^{4}$ Departemen Klinik, Reproduksi, Patologi, dan Nutrisi, Fakultas Kedokteran Hewan, \\ Universitas Nusa Cendana, Kupang. \\ ${ }^{5}$ Klinik Hewan Calico, Jl. Raya Tajem, Maguwoharjo, Depok, Sleman, Yogyakarta, 55281. \\ ${ }^{6}$ Klinik Hewan Griya Satwa Lestari J1. Kumudasmoro Utara No.17, Bongsari, Semarang Barat, \\ Kota Semarang, Jawa Tengah 50148. \\ ${ }^{7}$ Klinik Hewan Kayu Manis, Jl. Gambiran No.52, Pandeyan, Umbulharjo, \\ Kota Yogyakarta 55161 \\ *Email: indarjulianto@ugm.ac.id
}

Naskah diterima: 3 Oktober 2020, direvisi: 27 November 2020, disetujui: 8 Januari 2021

\begin{abstract}
Diarrhea is a disease that often found in dogs and Escherichia coli is one of the causes. The purpose of this study was to determine the diagnose of diarrhea in dogs caused by E. coli and determine the choice of antibiotics as therapy. A total of seven dogs with diarrhea were used in this study. All dogs were physically examined and $E$. coli was identified from stool samples. Fecal samples were inoculated on Harlequin ${ }^{\mathrm{TM}}$ E. coli/Coliform Medium, then incubated at $37^{\circ} \mathrm{C}$ for 24 hours. The growing colonies were observed, and Gram stained followed by examined microscopically. The bacteria tested for their sensitivity to amoxicillin, chloramphenicol, doxycycline and enrofloxacin using the diffusion disk method, and the growth zones were measured and compared with the standard. The results showed that E. coli was found in 3 out of 7 fecal samples of dog with diarrhea. All of the bacteria were sensitive to chloramphenicol and one isolate was sensitive to amoxicillin, but the other isolates were intermediate to resistant toward amoxicillin, doxycycline and enrofloxacin. To concluded, E. coli can be identified in $43 \%$ of dogs with diarrhea and chloramphenicol is the antibiotic of choice for therapy.
\end{abstract}

Keywords : antibiotic resistant; chloramphenicol; diarrhea; dog; Escherichia coli

\begin{abstract}
Abstrak
Diare adalah penyakit yang sering ditemukan pada anjing dan Escherichia coli merupakan salah satu yang dianggap sebagai penyebabnya. Tujuan dari penelitian ini adalah menentukan diagnosis diare pada anjing yang disebabkan E. coli dan menentukan pilihan antibiotika yang tepat sebagai terapi. Sebanyak tujuh anjing diare digunakan dalam penelitian ini. Semua anjing diperiksa secara fisik dan E. coli diidentifikasi dari sampel fesesnya. Sampel feses dipupuk pada media Harlequin ${ }^{\mathrm{TM}}$ E. coli/Coliform Medium, diinkubasi pada $37{ }^{\circ} \mathrm{C}$ selama 24 jam. Koloni yang tumbuh diamati, dicat Gram dan diperiksa di bawah mikroskop. Bakteri selanjutnya diuji sensitivitasnya terhadap amoksisilin, kloramfenikol, doksisiklin dan enrofloksasin menggunakan metode disk difusi, zona pertumbuhan diukur dan hasilnya dibandingkan dengan standar. Hasil penelitian menunjukkan bahwa E. coli ditemukan pada 3 dari 7 sampel feses anjing diare. Semua bakteri tersebut sensitif terhadap
\end{abstract}


kloramfenikol dan 1 isolat sensitif terhadap amoksisilin, tetapi isolat lain bersifat intermedier sampai resisten terhadap amoksisilin, doksisiklin dan enrofloksasin. Kesimpulan penelitian ini adalah E. coli dapat diidentifikasi dari $43 \%$ anjing diare dan kloramfenikol adalah antibiotika pilihan utama untuk terapi.

Kata kunci : anjing; diare; Escherichia coli; kloramfenikol; resistensi antibiotika

\section{Pendahuluan}

Diare adalah gejala gangguan gastrointestinal yang ditandai dengan peningkatan konsistensi, frekuensi dan volume feses, yang dapat diderita oleh anjing berbagai ras baik pada umur muda maupun dewasa. Gangguan atau penyakit ini seringkali mengakibatkan kematian yang cukup tinggi apabila tidak segera diobati dengan tepat sesuai penyebabnya. Diare pada anjing dapat disebabkan antara lain a) bahan non infeksius seperti intoleransi pakan, obat, dan b) agen infeksius teridiri dari virus, bakteri, parasit, dan fungi (Marks et al., 2011; Li et al., 2014; Hsu et al., 2016; Westermarck et al., 2016). Salah satu bakteri penyebab diare pada anjing adalah $E$. coli, dan beberapa strain E. coli yang berperan sebagai penyebab diare pada hewan diduga kuat dapat menular kepada manusia (bersifat zoonosis). Jalur penularan E. coli antara hewan dan manusia kemungkinan dapat terjadi melalui kontak langsung, kontak dengan kotoran hewan atau melalui rantai makanan yang tercemar (JayRussell et al., 2014). Anjing dan kucing diduga memiliki peran dalam penularan Shiga toxinproducer Escherichia coli (STEC) pada manusia melalui kontak dengan hewan (Beutin, 1999; Ewers et al., 2010; Bélanger et al., 2011; Marks et al, 2011; Salehi et al., 2011; Bentancor et al., 2012; Torkan et al., 2016; Poirel et al., 2018; Dewandaru et al., 2019). Oleh karena itu informasi berkaitan adanya $E$. coli pada anjing penderita diare sangat penting, dalam rangka untuk pengobatan pada anjing maupun kewaspadaan penanggulangan penularan dari hewan ke manusia.

Kasus diare sering ditemukan pada anjing dalam praktek dokter hewan di Indonesia, tetapi diagnosisnya sering hanya didasarkan pada Pemeriksaan fisik saja, sehingga informasi berkaitan dengan $E$. coli yang berperan dalam menimbulkan diare sangat minim. Diagnosis penyakit ini tidak akurat apabila ditentukan hanya berdasarkan gejala klinis, sehingga harus diteguhkan dengan identifikasi bakteri secara laboratoris. Beberapa metode isolasi dan identifikasi adanya E. coli telah banyak dikembangkan termasuk metode konvensional dan molekuler (DeAlmeida et al., 2012; Yousif et al., 2016). Sayangnya isolasi dan identifikasi menggunakan metode konvensional memerlukan waktu beberapa hari, sehingga penentuan diagnosis dan terapi yang tepat akan tertunda. Identifikasi E. coli dapat juga dilakukan secara molekuler dengan metode polymerase chain ceaction (PCR), namun demikian metode ini membutuhkan primer spesifik dan peralatan khusus yang belum dipunyai setiap laboratorium, sehingga biaya identifikasinya masih cukup mahal. Alasan lamanya waktu dan tingginya biaya membuat identifikasi $E$. coli dengan metode tersebut sangat jarang dilakukan di dunia praktek hewan kesayangan. Beberapa media selektif telah dikembangkan, salah satunya adalah harlequin yang dalam waktu maksimal 24 jam dapat mengidentifikasi E. coli yang sekaligus dapat membedakan dengan coliform (Baylis dan Patrick, 1999; Dewandaru et al., 2019). Penggunaan media selektif ini akan cukup membantu mempercepat penentuan diagnosis dan terapi penyakit yang disebabkan oleh E. coli, termasuk diare pada anjing.

Pengobatan atau terapi suatu penyakit sebaiknya didasarkan atas penyebab utamanya, dengan menggunakan obat yang sesuai. Pengobatan untuk penyakit yang disebabkan oleh bakteri adalah antibakteri atau antibiotika, dan seharusnya pemilihannya didasarkan pada hasil uji sensitifitas bakteri terhadap antibiotika. Penggunaan antibiotika yang tidak sesuai aturan akan memicu terjadinya resistensi bakteri terhadap antibiotika (Indarjulianto et al., 2018). Escherichia coli dianggap sebagai reservoir utama dari gen resistensi yang mungkin bertanggung jawab atas kegagalan pengobatan, baik pada kedokteran manusia maupun kedokteran hewan. Secara umum, resistensi antimikroba pada E. coli dianggap sebagai salah satu tantangan utama pada manusia dan hewan yang perlu dipertimbangkan sebagai masalah kesehatan masyarakat yang 
nyata (Poirel et al.2018). Tujuan dari penelitian ini adalah menentukan diagnosis penyakit diare anjing yang disebabkan $E$. coli dan pilihan antibiotika berdasarkan uji sensitifitasnya terhadap antibiotika. Hasil penelitian ini akan dapat dipakai sebagai dasar diagnosis dan pengobatan pada anjing penderita diare.

\section{Materi dan Metode}

Penelitian ini menggunakan 7 pasien anjing penderita diare yang tidak dibedakan umur, ras dan jenis kelamin. Semua anjing diperiksa secara fisik, terutama fesesnya yang berbentuk cair sebagai dasar diagnosis diare. Sampel anjing merupakan pasien yang diperiksakan ke klinik hewan dan pengambilan dan pemeriksaan sampel feses telah mendapatkan persetujuan dari pemilik. Sampel feses anjing diare diambil dengan swab steril, dipupuk pada media selektif E. coli (Harlequin TM E. coli/Coliform Medium (CM), Neogen Culture Culture Media, UK) dan diinkubasi pada $37^{\circ} \mathrm{C}$ selama 24 jam. Koloni yang tumbuh diamati, dicat Gram, kemudian diperiksa di bawah mikroskop untuk pemeriksaan bentuk sel dan warnanya. Bakteri E. coli diidentifikasi berdasarkan pertumbuhan koloni pada $\mathrm{CM}$ dan hasil pengecatan Gram, yaitu koloni berwarna biru, sel berbentuk batang dan bersifat Gram negatif (Baylis dan Patrick, 1999). Bakteri selanjutnya diuji sensitifitasnya terhadap amoksisilin, kloramfenikol, doksisiklin dan enrofloksasin menggunakan metode disk difusi di laboratorium Departemen Ilmu Penyakit Dalam FKH-UGM, dan hasil yang didapatkan diinterpretasi berdasarkan standar seperti yang telah dikerjakan sebelumnya (Tabel 1; Fouad, 2011; Sarker et al., 2014; CLSI, 2012, 2017; Indarjulianto et al., 2018; Maida dan Lestari, 2019). Hasil penelitian selanjutnya dianalisis secara deskriptif.

\section{Hasil dan Pembahasan}

Diagnosis diare pada anjing secara klinis sebaiknya dilanjutkan dengan peneguhan agen penyebabnya, sehingga diagnosis dan terapinya dapat ditentukan lebih tepat. Berdasarkan pemeriksaan fisik dengan feses cair, 7 ekor anjing yang digunakan di dalam penelitian ini didiagnosis diare, sehingga sampel feses diambil untuk didentifikasi adanya E. coli. Hasil identifikasi bakteri terhadap 7 sampel feses tersebut didapatkan 3 dari 7 (43\%) feses anjing tumbuh dengan koloni berwarna biru pada media CM. Hasil pewarnaan Gram didapatkan bakteri berbentuk batang dan bersifat Gram-negatif (Gambar 1). Bedasarkan ciri-ciri tersebut isolat diidentifikasi sebagai $E$. coli (Baylis dan Patrick, 1999; Carter dan Cole, 1990; Quinn et al., 2011). Sementara itu, 4 dari 7 (57\%) sampel lainnya negatif E. coli. Hasil ini sesuai dengan penelitian lain, yang membuktikan adanya $E$. coli dari feses anjing penderita diare (Beutin, 1999; Goffaux et al., 2000; Marks et al., 2011; Dewandaru et al., 2019). Penggunaan media selektif CM telah dapat mempercepat identifikasi bakteri E. coli, yang dapat diaplikasikan pada dunia praktek dokter hewan, tetapi untuk mengetahui karakter lebih mendalam masih perlu dilakukan penelitian lanjutan. Penggunaan media Coliform ini sangat membantu terutama untuk dapat segera menentukan diagnosis kausatif penyebab diare. Selain itu, langkah ini dapat dipakai sebagai skrining awal, sehingga karakterisasi bakteri lanjutan termasuk molekuler dapat dilakukan lebih cepat (Gizzi et al., 2014).

Escherichia coli yang diisolasi dari feses anjing diare pada penelitian ini kemungkinan mempunyai peranan penting sebagai penyebab utama diare, tetapi jenis faktor virulensinya belum diketahui. Berdasarkan faktor virulensi, E. coli patogen diklasifikasikan menjadi: 1) patotipe: enteropathogenic E. coli (EPEC); 2)

Tabel 1. Acuan penentuan sifat resistensi E. coli terhadap antibiotika

\begin{tabular}{lccc}
\hline \multicolumn{1}{c}{ Antibiotika } & & Zona hambat pertumbuhan bakteri & \\
& Sensitif $(\mathrm{mm})$ & Intermedier $(\mathrm{mm})$ & $\leq 15-16$ \\
\hline Amoksisilin $(30 \mu \mathrm{g})$ & $\geq 17$ & $13-17$ & $\leq 12$ \\
Kloramfenikol $(30 \mu \mathrm{g})$ & $\geq 18$ & $13-15$ & $\leq 12$ \\
Doksisiklin $(30 \mu \mathrm{g})$ & $\geq 16$ & $17-20$ & $\leq 16$ \\
Enrofloksasin $(5 \mu \mathrm{g})$ & $\geq 21$ & & \\
\hline
\end{tabular}




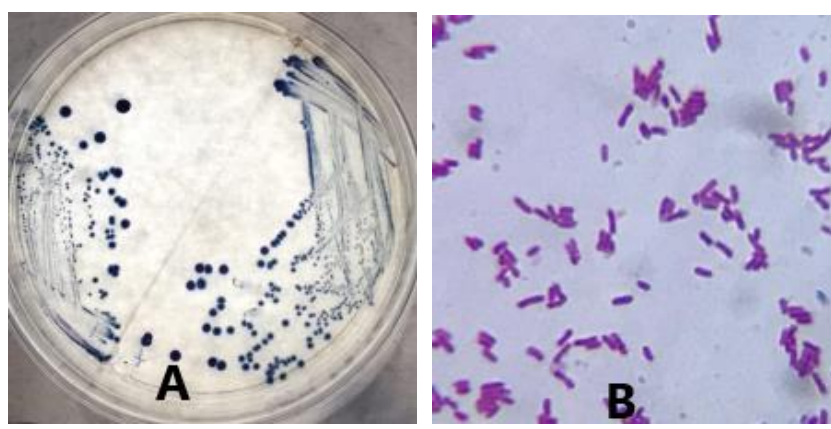

Gambar 1. Koloni sampel feses anjing penderita diare, yang diidentifikasi sebagai Escherichia coli pada media CM (A) dan hasil pengecatan Gram (B)

enterotoxigenic E. coli (ETEC); 3) Shiga toxinproducing E. coli (STEC); 4) enterohemorrhagic E. coli (EHEC)]; 5) diffusely adherent E. coli (DAEC); 6) enteroinvasive E. coli (EIEC), dan 7) enteroaggregative E. coli (EAEC) (Beutin, 1999; Croxen et al., 2013). Menurut Marks et al. (2011) beberapa $E$. coli termasuk mikro flora normal dalam usus, tetapi beberapa kasus gastroenteritis terkait dengan keberadaan faktor virulensi $E$. coli. Beberapa laporan menyebutkan bahwa diare pada anjing dapat disebabkan oleh enteropathogenic Escherichia coli (EPEC) dan E. coli yang memiliki gen eae (Beutin, 1999, Goffaux et al., 2000, Nakazato et al., 2004; Gouveia et al., 2013; Kjaergaard et al., 2016; Coura et al., 2018). PuñoSarmiento et al. (2013) juga telah mengidentifikasi E. coli pada 68 ekor anjing penderita diare, yang 17 diantaranya $(25,0 \%)$ mempunyai gen virulensi, yaitu gen eaeA (EPEC) pada 12 dari $68(17,6 \%)$ dan gen aggR (EAEC) pada 5 dari 68 (7,4\%). Beberapa strain E. coli dapat menyebabkan lesi attachment dan effacing (A/E) pada mukosa usus yang menyebabkan diare (Beutin, 1999, Goffaux et al., 2000, Nakazato et al., 2004). Sepuluh isolat dari 10 anjing terbukti memiliki setidaknya satu dari gen virulensi EPEC atau STEC (Salehi et al.,
2011). Dua puluh delapan isolat aEPEC ditemukan dari 48 sampel feses eae-positif, 24 dari hewan diare dan 4 dari yang non-diare. Penanda fenotipe dan genotipik aEPEC yang diisolasi dari anjing penderita diare dan non-diare serupa dengan yang ditemukan pada isolat yang sembuh dari penyakit manusia (De Almeida et al., 2012). Arais et al., (2018) melaporkan adanya potensi risiko zoonosis karena beberapa galur aEPEC dan strain dari serotipe pada anjing mempunyai gen virulensi yang biasa ditemukan pada galur patogen manusia, yang secara filogenetik sangat dekat. Yousif et al. (2016) menyarankan agar anjing dan anak anjing dianggap sebagai reservoir penting bagi $E$. coli O157: H7 yang merupakan salah satu penyebab utama diare dan penyakit lain pada manusia. Oleh karena itu, karakterisasi faktor virulensi dari isolat E. coli yang diidentifikasi pada penelitian ini perlu diteliti lebih lanjut, baik dengan metode konvensional maupun molekuler.

Bakteri-bakteri yang telah diidentifikasi sebagai E. coli pada penelitian ini telah diuji sensitivitasnya terhadap antibiotika dengan hasil 1 dari 3 isolat sensitif dan 2 dari 3 isolat resisten terhadap amoksisilin. Semua E. coli sensitif terhadap kloramfenikol, dan bersifat intermedier dan resisten terhadap doksisiklin dan enrofloksasin (Gambar 2; Tabel 2). Resistensi E. coli juga telah dilaporkan oleh beberapa peneliti. Puño-Sarmiento et al. (2013) melaporkan bahwa beberapa strain E. coli penyebab diare anjing menunjukkan resistensi terhadap empat atau lebih antimikroba. Beberapa isolat menunjukkan resistensi terhadap enrofloksasin atau siprofloksasin yang biasa digunakan dalam praktik kedokteran hewan, mamun beberapa strain menunjukkan resistensi terhadap antimikroba yang tidak biasa dalam praktik kedokteran hewan (aztreonam, imipenem, asam nalidixic dan kloramfenikol). Ojo et al. (2014)

Tabel 2. Hasil uji Resistensi Escherichia coli isolat Anjing terhadap antibiotika

\begin{tabular}{lcccccc}
\hline \multirow{2}{*}{ Antibiotika } & \multicolumn{4}{c}{ Hasil zona hambat pertumbuhan bakteri dan interpretasi } \\
\cline { 2 - 7 } & \multicolumn{2}{c}{ Sensitif } & \multicolumn{2}{c}{ Intermedier } & \multicolumn{2}{c}{ Resisten } \\
\cline { 2 - 7 } & $\mathrm{mm}$ & Jumlah (\%) & $\mathrm{mm}$ & Jumlah (\%) & $\mathrm{mm}$ & Jumlah (\%) \\
\hline Amoksisilin & 20 & $1(33)$ & - & 0 & $<12$ & $2(67)$ \\
Kloramfenikol & $>18$ & $3(100)$ & - & 0 & - & 0 \\
Doksisiklin & - & 0 & 14 & $2(67 \%)$ & $<12$ & $1(33)$ \\
Enrofloksasin & - & 0 & - & 0 & $<16$ & $3(100)$ \\
\hline
\end{tabular}


melaporkan bahwa 16 dari $22(72,7 \%)$ isolat $E$. coli dari feses anjing mempunyai sifat resisten terhadap setidaknya tiga antimikroba dari kelas yang berbeda, dan mendapatkan 18 pola resistensi antimikroba yang berbeda di antara isolat. Isolat tersebut menunjukkan resisten terhadap ampisilin $(86,4 \%)$, kloramfenikol $(36,4 \%)$, ciprofloksasin $(4,5 \%)$, gentamisin $(18,2 \%)$, kanamisin $(68,2 \%)$, asam nalidiksat $(22,7 \%)$, neomisin $(40,9 \%)$, norfloksasin $(9,1 \%)$, streptomisin $(63,6 \%)$, sulfametoksazol/trimetoprim $(63,6 \%)$ dan tetrasiklin (77,3\%). Escherichia coli yang diisolasi dari diare anak-anak menunjukkan resisten terhadap ceftazidime (91\%), efuroksim (100\%), gentamisin (78\%), ceftriaxone $(91 \%)$, ofloxacin $(78 \%)$ dan resisten terhadap augumentin (100\%) (Ugwu et al., 2017). Kibret dan Abera (2011) melaporkan bahwa dari 446 E. coli dari manusia menunjukkan sifat resistensi yang tinggi terhadap amoksisilin $(85 \%)$ dan tetrasiklin $(72,6 \%)$.

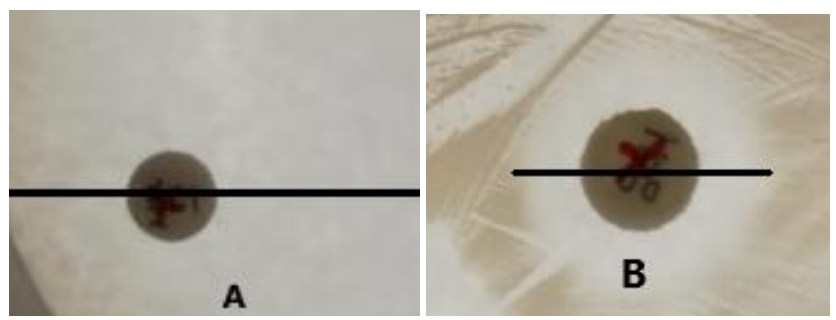

Gambar 2. Contoh hasil uji sensitifitas $E$ coli yang sensitif terhadap amoksisilin (A) dan resiten terhadap doksisiklin (B)

Isolat E. coli pada penelitian ini masih sensitif terhadap antibiotika kloramfenikol, hal ini kemungkinan karena antibiotika ini jarang digunakan untuk pengobatan pada hewan. Berbeda dengan antibiotika lainnya seperti amoksisilin, doksisiklin dan enrofloksasin yang kemungkinan sering digunakan dalam pengobatan penyakit hewan, sehingga memungkinkan terjadinya sifat resistensi terhadap antibiotika tersebut. Pada penelitian in vitro sebelumnya diketahui bahwa resistensi bakteri E. coli terhadap oksitetrasiklin dapat terjadi karena pemberian antibiotika yang kurang tepat, baik karena ketidak tepatan dosis yang diberikan ataupun waktu pemberian yang terlalu lama (Indarjulianto et al., 2018). Resistensi bakteri terhadap antibiotika dapat dikode oleh gen, baik gen yang ada di plasmid ataupun gen yang ada pada kromosom dari bakteri (Soedarmanto et al., 1995; Bennett, 2008; Soedarmanto et al.,
2011; Poirel et al.2018). Peningkatan jumlah gen resistensi telah diidentifikasi pada isolat $E$. coli selama beberapa dekade terakhir, dan banyak dari gen resistensi ini diperoleh melalui transfer gen horizontal, karena bakteri ini dapat bertindak sebagai donor maupun penerima gen resistensi (Poirel et al.2018). Sifat resistensi isolat E. coli pada penelitian ini perlu diteliti lebih lanjut tentang kemungkinan adanya gen yang mengkode sifat resistensi yang dipunyai.

\section{Kesimpulan}

Penelitian disimpulkan bahwa E. coli dapat diidentifikasi dari $43 \%$ anjing diare dan kloramfenikol adalah antibiotika pilihan utama untuk terapi.

\section{Ucapan Terima Kasih}

Penelitian ini merupakan bagian dari Penelitian PTUPT UGM No. 1824/UN1/DITLIT/ DIT-LIT/LT/2018 yang didanai oleh Dirjen Dikti, Kemenristek-Dikti, Indonesia. Terimakasih kepada Departemen Ilmu Penyakit Dalam FKH-UGM yang telah memberikan fasilitas laboratorium.

\section{Daftar Pustaka}

Arais, L.R., Barbosa, A.V., Andrade, J.R.C., Gomes, T.A.T., Asensi, M.D., Aires, C.A.M., and Cerqueira, A.M.F. (2018). Zoonotic potential of atypical enteropathogenic Escherichia coli (aEPEC) isolated from puppies with diarrhoea in Brazil. Vet Microbiol. 227: 45-51. https:// doi.org/10.1016/j.vetmic.2018.10.023.

Baylis, C.L., and Patrick, M. (1999). Comparison of a range of Chromogenic media for enumeration of total Coliforms and Escherichia coli in foods. Leatherhead International Technical Notes. No.135: 99.

Bélanger, L., Garenaux, A., Harel, J., Boulianne, M., Nadeau, E., and Dozois, C.M, (2011). Escherichia coli from animal reservoirs as a potential source of human extraintestinal pathogenic E. Coli. FEMS Immunol Med Microbiol. 62(1): 1-10. https://doi. org/10.1111/j.1574-695X.2011.00797.x 
Bennett, P.M. 2008. Plasmid encoded antibiotic resistance: acquisition and transfer of antibiotic resistance genes in bacteria (Review). British J Pharmacol. 153: S347S357.

Bentancor,A., Rumi, M.V., Carbonari, C., Gerhardt, E., Larzábal, M., Vilte, D.A., PistoneCreydt, V., Chinen, I., Ibarra, C., Cataldi, A., and Mercado, E.C. (2012). Profile of Shiga toxin-producing Escherichia coli strains isolated from dogs and cats and genetic relationships with isolates from cattle, meat and humans. Vet Microbiol. 156(34): 336-342. ISSN 0378-1135. https://doi. org/10.1016/j.vetmic.2011.10.030.

Beutin, L. 1999. Escherichia coli as a pathogen in dogs and cats. Vet Res.: 30(2-3):285-298.

Carter, G.R., and Cole, J.R.. (1990). Diagnostis Prcedure in Veterinary Bakteriology and Mycology. Fifth Ed. Academic Press: California.

Coura, F.M., Diniz, A.N., Oliveira Jr, C.A., Lage, A.P., Lobato, F.C.F., Heinemann, M.B., and Silva, R.O.S. (2018). Detection of virulence genes and the phylogenetic groups of Escherichia coli isolated from dogs in Brazil. Ciência Rural, 48(2): 1-6. https:// doi.org/10.1590/0103-8478cr20170478.

CLSI. Clinical and Laboratory Standards Institute. (2012). Methods for Dilution Antimicrobial Susceptibility Tests for Bacteria That Grow Aerobically. Approved Standard, M07-A9. Ninth ed. CLSI, Wayne, PA, USA.

CLSI. Clinical and Laboratory Standards Institute. (2017). M100-Performance Standards for Antimicrobial Disk and Dilution Susceptibility Testing. Approved Standard, M10. 27ed., CLSI, Wayne, PA, USA.

Croxen, M.A., Law, R.J., Scholz, R., Keeney, K.M., Wlodarska, M., and Finlay, B.B. (2013). Recent advances in understanding enteric pathogenic Escherichia coli. Clin Microbiol Rev. 26: 822-880.

De Almeida, P.M.P., Arais, L.R., Andrade, J.R.C., Prado, E.H.R.B., Irino, K., and Cerqueira, A.M.F. (2012). Characterization of atypical
Enteropathogenic Escherichia coli (aEPEC) isolated from dogs. Vet Microbiol. 158 (34): 420-424.

Dewandaru, R.A., Indarjulianto, S., Yanuartono, Y., Nururrozi A., Purnamaningsih, H. and Rusmihayati. (2019). Diare Disebabkan Infeksi Escherichia coli pada Anjing. JIPVET. 9(2): 38- 43.

Ewers, C., Grobbel, M., Stamm, I., Kopp, P.A., Diehl, I., Semmler, T., Fruth, A., Beutlich, J., Guerra, B., Wieler, L.H., and Guenther, S. (2010). Emergence of human pandemic O25:H4-ST131 CTX-M-15 extended-spectrum- $\beta$-lactamase-producing Escherichia coli among companion animals. $J$ Antimicrob Chemother. 65(4): 651-660. https://doi.org/10.1093/jac/dkq004.

Fouad, Z. (2011). Antimicrobial Disk Diffusion Zone Interpretation Guide. 10.13140/ RG.2.2.13801.70240.

Gizzi, A.B.R., Oliveira, S.T., Leutenegger, C.M., Estrada, M., Kozemjakin, D.A. Stedile, R., Marcondes, M., and Biondo, A.W. (2014). Presence of infectious agents and coinfections in diarrheic dogs determined with a real-time polymerase chain reaction-based panel. BMC Vet Res. 10(23): 1-8.

Goffaux, F., China, B., Janssen, L., and Mainil, J. (2000). Genotypic characterization of enteropathogenic Escherichia coli (EPEC) isolated in Belgium from dogs and cats. Res. Microbiol. 151: 865-871.

Gouveia, E.M.M.F., Silva, I.S., Nakazato, G., Onselem, V.J.V., Corrêa, R.A.C., Araujo, F.R., and Chang, M.R.. (2013). Action of phosphorylated mannanoligosaccharides on immune and hematological responses and fecal consistency of dogs experimentally infected with enteropathogenic Escherichia coli strains. Brazilian J Microbiol. 44(2): 499-504. https://doi.org/10.1590/S151783822013000200027.

Hsu, H., Lin, T., Wu, H. Lin, L.S., Chung, C.S., Chiou, M.T., and Lin, C.N. (2016). High detection rate of dog circovirus in diarrheal dogs. BMC Vet Res. 12(116): 1-6. https:// doi.org/10.1186/s12917-016-0722-8 
Indarjulianto S., Nururrozi, A., Yanuartono, Y., Widyarini, S., Rusmihayati, Pramono, VJ., and Wikan Sari, P. 2018. Perkembangan Resistensi Escherichia coli terhadap oksitetrasiklin. J. Sain Vet. 36 (1): 11-15.

Jay-Russell, M.T., Hake, A.F., Bengson, Y., Thiptara, A., and Nguyen, T. (2014) Prevalence and Characterization of Escherichia coli and Salmonella Strains Isolated from Stray Dog and Coyote Feces in a Major Leafy Greens Production Region at the United States-Mexico Border. PLoS ONE. 9(11): e113433.

Kibret, M., and Abera, B. (2011). Antimicrobial susceptibility patterns of $E$. coli from clinical sources innortheast Ethiopia. African health sci. 11(1-1): S40-S45.

Kjaergaard, A.B., Carr, A.P., and Gaunt, M.C. (2016). Enteropathogenic Escherichia coli (EPEC) infection in association with acute gastroenteritis in 7 dogs from Saskatchewan. Can Vet J. 57(9): 964-968.

Li, W., Gong, P., Ying, M., Li, J.H., Yang, J., Li, H., Yang, Z.T., Zhang, G.C., and Zhang, X.C. (2014). Pentatrichomonas hominis: first isolation from the feces of a dog with diarrhea in China. Parasitol Res. 113: 17951801. https://doi.org/10.1007/s00436-0143825-9.

Maida, S., and Lestari, K.U.P. (2019). Aktivitas Antibakteri Amoksisilin Terhadap Bakteri Gram Positif Dan Bakteri Gram Negatif. Jurnal Pijar Mipa. 14(3): 189-191.

Marks, S.L., Rankin, S.C., Byrne, B.A., and Weese, J.S. (2011). Enteropathogenic Bacteria in Dogs and Cats: Diagnosis, Epidemiology, Treatment, and Control. J Vet Intern Med. 25:1195-1208.

Nakazato, G., Gyles, C., Ziebell, K., Keller, R., Trabulsi, L.R., Gomes, T.A., Irino, K., Da Silveira, W.D., Pestana De Castro, A.F. (2004). Attaching and effacing Escherichia coli isolated from dogs in Brazil: characteristics and serotypic relationship to human enteropathogenic E coli (EPEC). Vet. Microbiol. 101: 269-277.
Ojo, O.E., Bello, A.O., Amosun, E.A., Ajadi, R.A. (2014). Multidrug resistant ultidrug resistant verocytotoxin-producing erocytotoxinproducing Escherichia coli scherichia coliO157:H7 in the faeces of diarrhoeic and O157:H7 in the faeces of diarrhoeic and non-diarrhoeic dogs in Abeokuta, Nigeria on-diarrhoeic dogs in Abeokuta, Nigeria. Vet. Archiv. 84: 63-73.

Poirel, L., Madec, J.Y., Lupo, A., Schink, A.K., Kieffer, N., Nordmann, P. and Schwarz, S. (2018). Antimicrobial Resistance in Escherichia coli. In Antimicrobial Resistance in Bacteria from Livestock and Companion Animals (eds S. Schwarz, L.M. Cavaco and J. Shen). doi:10.1128/9781555819804.ch13.

Puño-Sarmiento, J., Medeiros, L., Chiconi, C., Martins, F., Pelayo, J., Rocha, S., Blanco, J., Blanco, M., Zanutto, M., Kobayashi, R., and Nakazato, G. (2013). Detection of diarrheagenic Escherichia coli strains isolated from dogs and cats in Brazil. Vet Microbiol. 166(3-4): 676-680.

Quinn, P.J., Markey, B.K., Leaonard, F.C., Fitzpatrick, E.S., Fanning, S., and Hartigan P.J. (2011). Veterinary microbiology and microbial disease. 2nd ed. Oxford, OX: John Wiley \& Sons.

Salehi Z.T., Badouei, M.A., and Gohari, I, M. 2011. Molecular detection and antibacterial susceptibility of enteropathogenic Escherichia coli (EPEC) and shigatoxigenic Escherichia coli (STEC) strains isolated from healthy and diarrhoeic dogs. Comp Clin Pathol. 20:585-589. https://doi. org/10.1007/s00580-010-1037-y.

Sarker, M.R., Islam, K.N., Huri, H.Z., Hasan, I., Hosen, B., Rahman, M., Mohammad, N., and Sarker, Z.I. (2014). Studies of the Impact of Occupational Exposure of Pharmaceutical Workers on the Development of Antimicrobial Drug Resistance. J Occupational Health. 56: 260-270. 10.1539/joh.14-0012-OA.

Soedarmanto, I., Kanbar, T., Ülbegi-Mohyla, H., Hijazin, M., Alber J., Lämmler, C., Akineden, O., Weiss, W., Moritz, A., and 
Zschöck, M. (2011). Genetic relatedness of methicillin-resistant Staphylococcus pseudintermedius (MRSP) isolated from a dog and the dog owner. Res. Vet. Sci. 91: e-25-e27.

Soedarmanto, I., Schwarz, S., Liebisch, B., and Lämmler, C. (1995). Tetracycline resistance determinants among streptococci of serological group $\mathrm{G}$ and L. Vet Microbiol. 45(4): 331-337.

Torkan, S., Bahadoranian, M.A., Khamesipour, F., and Anyanwu, M.U. (2016). Detection of virulence and antimicrobial resistance genes in Escherichia coli isolates from diarrhoiec dogs in Iran. Arch med vet. 48(2): 181-190. https://dx.doi.org/10.4067/S0301732X2016000200008.
Ugwu, M.C., Edeani, G.I., Ejikeugwu, C.P., Okezie, U., Ejiofor, S.O. (2017) Antibiotic Susceptibility Profile of Escherichia coli and Salmonella Causing Childhood Diarrhoea in Awka Municipality, Southeastern Nigeria. Clin Microbiol. 6: 277. doi:10.4172/2327-5073.1000277.

Westermarck, E. (2016). Chronic diarrhea in dogs: what do we actually know about it? Top Companion Anim Med. 31(2): 78-84.

Yousif, A.A., Hasan, M.S., and Alwan, M.J. (2016). Clinical and molecular study of $E$. coli O157:H7 isolated from Diarrheic and non-diarrheic dogs. MRVSA. 5(2): 1-10. Culp, W.T.N. (2013). Surgical Treatment of Splenic Disease. In Small Animal Soft Tissue Surgery. Monnet, E. (Ed). $1^{\text {st }}$ ed. Wiley-Blackwell, Iowa. 